\title{
Identification of priority areas for plant conservation in Madagascar using Red List criteria: rare and threatened Pandanaceae indicate sites in need of protection
}

\author{
Martin W. Callmander, George E. Schatz, Porter P. Lowry II, Michel O. Laivao, Jeannie Raharimampionona, \\ Sylvie Andriambololonera, Tantely Raminosoa and Trisha K. Consiglio
}

\begin{abstract}
A major problem in establishing effective protocols for conserving Madagascar's biodiversity is the lack of reliable information for the identification of priority sites in need of protection. Analyses of field data and information from herbarium collections for members of the plant family Pandanaceae (85 spp. of Pandanus; 6 spp. of Martellidendron) showed how risk of extinction assessments can inform conservation planning. Application of IUCN Red List categories and criteria showed that $91 \%$ of the species are threatened. Mapping occurrence revealed centres of richness and rarity as well as gaps in Madagascar's existing protected area network. Protection of 10 additional sites would be required to encompass the 19 species currently lacking representation in the reserve network, within which east coast littoral forests are particularly under represented and important. The effect of scale on assessments of risk of extinction was explored by applying different grid
\end{abstract}

cell sizes to estimate area of occupancy. Using a grid cell size within the range suggested by IUCN overestimates threatened status if based solely upon specimen data. For poorly inventoried countries such as Madagascar measures of range size based on such data should be complemented with field observations to determine population size, sensitivity to disturbance, and specific threats to habitat and therefore potential population decline. The analysis of such data can make an important contribution to the conservation planning process by identifying threatened species and revealing the highest priority sites for their conservation.

Keywords IUCN Red List, Madagascar, Pandanaceae, protected areas, threatened species.

This paper contains supplementary material that can only be found online at http://journals.cambridge.org

\section{Introduction}

The Malagasy flora is characterized by high levels of diversity (12,000-14,000 species; Goodman \& Benstead, 2005; Phillipson et al., 2006) and endemism (>90\%; Schatz, 2001), and is threatened by unsustainable land use practices, such as shifting cultivation and fire, that have left $<10 \%$ of the original vegetation intact (Myers et al., 2000). Madagascar is regarded as a high priority

Martin W. Callmander (Corresponding author) Missouri Botanical Garden, P.O. Box 299, St. Louis, MO 63166-0299, USA, and University of Neuchâtel, Laboratoire de Botanique Evolutive, Case Postale 158, 2009 Neuchâtel, Switzerland. E-mail martin.callmander@mobot-mg.org

George E. Schatz, Porter P. Lowry II* and Trisha K. Consiglio Missouri Botanical Garden, P.O. Box 299 St. Louis, MO 63166-0299, USA.

Michel O. Laivao, Jeannie Raharimampionona, Sylvie Andriambololonera and Tantely Raminosoa Madagascar Research and Conservation Program, Missouri Botanical Garden, BP 3391 Antananarivo 101, Madagascar.

${ }^{*}$ Also at: Département Systématique et Evolution, Muséum National d'Histoire Naturelle, Case Postale 39, 57 rue Cuvier, 75231 Paris CEDEX 05, France.

Received 4 October 2005. Revision requested 24 April 2006. Accepted 13 February 2007. for conservation and for the study of evolutionary processes (Myers \& Knoll, 2001).

At the 2003 World Parks Congress in Durban, South Africa, the Malagasy President, Marc Ravalomanana, announced plans to triple the size of the protected areas network by 2008, from 1.7 to 6 million ha (nearly $10 \%$ of the country). This goal has been integrated into Phase 3 of the National Environmental Action Plan, and an initial set of target areas has been identified for inclusion in an expanded protected area network. However, research and analysis is needed to ensure maximal inclusion of the country's biodiversity. Application of the IUCN Red List criteria, a widely recognized tool for identifying threatened species, offers a powerful method to identify priority sites for protection by providing information on the conservation status of species in the wild (Rodrigues et al., 2006). In Madagascar, however, only 425 plant species have been assessed to date, of which only 210 were evaluated using the current criteria (IUCN, 2006). Many of the species that have not been assessed are so poorly known or rare that up-to-date distribution information is unavailable. To address this we have developed an efficient, robust procedure for 
evaluating restricted range plant species using primary occurrence data from herbarium collections and recent field observations (Schatz, 2002; Raharimampionona et al., 2006). This procedure also identifies sites with high species richness and concentrations of rare species that constitute prospective conservation priorities. Here we provide an example of the application of these complementary approaches using the plant family Pandanaceae.

Pandanaceae comprise four genera of arborescent or lianoid dioecious monocotyledons, two of which occur in Madagascar, Martellidendron (7 spp., all but one restricted to the island) and the widespread Paleotropical genus Pandanus (c. 600 spp., with 85 spp. endemic to Madagascar). The taxonomy of both genera has been revised recently (Laivao et al., 2000, 2006; Callmander et al., 2001, 2003a,b,c; Callmander \& Laivao, 2002) and, combined with information from recent field work, provides data suitable for illustrating our procedures for identifying conservation priorities. Species of Pandanaceae grow in all tropical forest types (dry to humid) and exhibit both widespread and restricted distributions. By applying IUCN Red List categories, calculating richness and rarity, and identifying areas with high diversity of endemic Malagasy Pandanaceae, we (1) illustrate how assessments using herbarium data can inform conservation planning, (2) show how the assessments can be used to evaluate the effectiveness of the existing protected area network and identify high priority sites for establishing new protected areas and/ or implementing alternative conservation strategies, (3) explore difficulties encountered in applying the Red List criteria relating to species distributions, and (4) illustrate some problems involved in using herbarium collections and field observations for Red List assessments and show how occurrence data can be analysed most effectively to provide useful interpretations for conservation.

\section{Methods}

Geographic data were compiled from $>550$ herbarium specimens representing the 91 endemic species of Malagasy Pandanaceae currently recognized (Fig. 1). Geographical coordinates for recent collections were recorded with a global positioning system or assigned post facto for older specimens using a gazetteer of botanical collecting localities (Schatz \& Lescot, 1996).

All Malagasy Pandanaceae were assessed using the IUCN Red List criteria (2001). Threatened species are those evaluated as Critically Endangered (CR), Endangered (EN), or Vulnerable (VU) with respect to extinction risk in the wild. We have argued elsewhere (Callmander et al., 2005) that the data deficient (DD) category should be used with parsimony to avoid underestimating the number of threatened species; this approach has been followed here. We used the four Red List criteria and subcriteria (IUCN, 2001) to determine threat: rapid population decline (Criterion A), limited geographic range and small population size linked with fragmentation, decline or fluctuation (Criteria B and C), and very small population size (Criterion D); we did not attempt to analyse extinction risk quantitatively using Criterion E.

For each species of Pandanaceae the geographical information system Arcview v. 3.3 (ESRI, Redlands, USA) was used to measure three parameters required for categorization using the Red List criteria (IUCN, 2001): extent of occurrence (EOO, minimum convex polygon containing all points of occurrence), area of occupancy (AOO, area estimated by superimposing a grid onto occurrence points and calculating the cumulative area of cells occupied by a species), and predicted future decline (PFD, estimated continuing reduction in a species' AOO). For species restricted to primary vegetation PFD was estimated using (AOO outside protected areas / total AOO) * 100, which is based on two assumptions that reasonably reflect the current situation for long-lived arborescent plants in Madagascar (Schatz et al., 2000; Good et al., 2006): within a few decades (3 generations for most Pandanaceae, estimated to be 30-50 years, depending on the species) ongoing habitat degradation and destruction will leave few significant areas of primary vegetation outside the protected area network, and loss of primary vegetation within protected areas will be minimal. While some unprotected areas may escape destruction (especially on steep or rugged terrain), it is nevertheless unlikely that many populations of long-lived plants will survive outside protected areas after 3 generations, given Madagascar's high rate of deforestation (Green \& Sussman, 1990; Achard et al., 2002). For species tolerant of habitat disturbance the calculation of PFD using this method would produce an overestimate of population reduction, and therefore we have evaluated such species based on direct field observations, indicating those known to be in continuing decline (without attempting to calculate PFD) so that the other Red List criteria can be applied.

The number of subpopulations within the total population of a species was estimated by overlaying a $10 * 10 \mathrm{~km}$ grid onto the mapped locality records and counting as distinct subpopulations the number of noncontiguous occupied cells or cell clusters (Schatz et al., 2000; Good et al., 2006). The number of subpopulations located within protected areas was determined by overlaying the distribution of subpopulations onto a map of protected areas.

The grid cell size used to calculate AOO influences Red List assessments (Willis et al., 2003) and because 


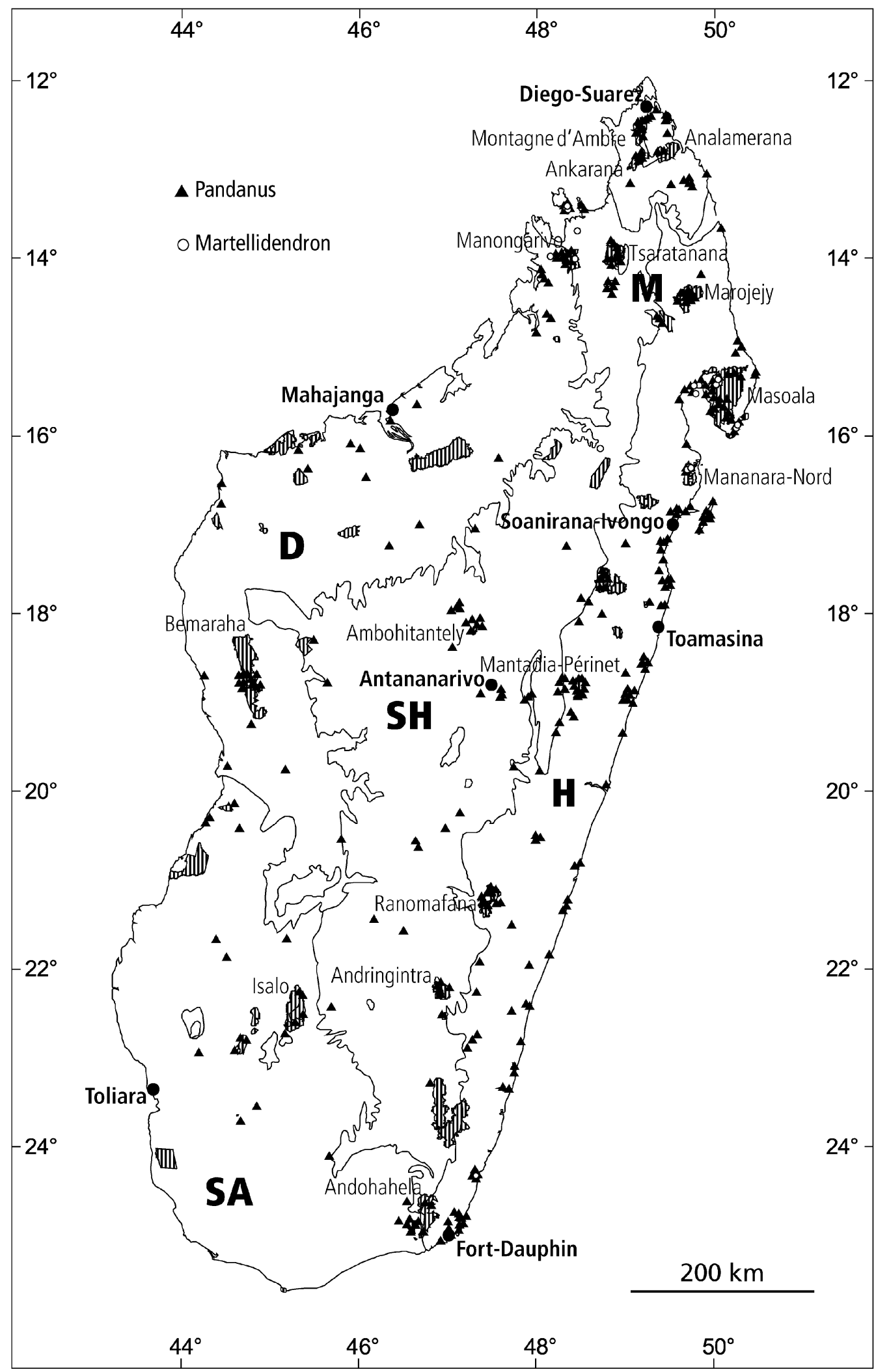

Fig. 1 All collections of the genera Martellidendron and Pandanus (Pandanaceae) in Madagascar mapped on the bioclimatic zones of Cornet (1974) simplified to five categories (D, Dry; H, Humid; M, Montane; SA, Subarid; SH, Subhumid; Schatz, 2000), and the main existing Protected Areas (vertical hatching). 
Malagasy Pandanaceae exhibit a wide range of distribution types they are an appropriate test group for evaluating the impact of using alternative grid cell sizes. The Red List guidelines (IUCN \& SSC, 2004) indicate that when selecting a grid the appropriate scale [for calculating AOO] depends on the taxon in question and the comprehensiveness of the distribution data', with a $2 * 2 \mathrm{~km}$ cell size suggested for most situations. Gardenfors (2001) recommended using smaller cells if a species is suspected of being CR but this presupposes an IUCN assessment (Willis et al., 2003). Schatz et al. (2000) used 10 * $10 \mathrm{~km}$ cells to analyse species in Madagascar's endemic plant families, a size considered to correspond to the average extent of an isolated subpopulation (Good et al., 2006). Willis et al. (2003) proposed using grid cells equal to $1 / 10$ of the length between the most distant pair of points of the EOO polygon. While this works well for approximately circular to oval distributions (length to width ratio $\leqslant 3: 1$ ), it is problematic for taxa with long, narrow distributions, yielding very large cells. We calculated estimates of AOO using three methods: that of (1) Willis et al. (2003), (2) Schatz et al. (2000), and (3) a $3 * 3 \mathrm{~km}$ grid. The latter corresponds closely to the near maximum for a taxon to be listed as CR under Red List criterion B2 (for which the threshold is $10 \mathrm{~km}^{2}$ ), and better reflects the overall poor level of geographic sampling of plants in Madagascar than a 2 * $2 \mathrm{~km}$ cell size.

In calculating EOO 'disjunctions or discontinuities within the overall range of a taxon' may be excluded (IUCN \& SSC, 2004), an idea explored but ultimately rejected by Willis et al. (2003) because an element of uncertainty is introduced. We tested the effect of removing clearly unsuitable habitat (sea and areas $>800 \mathrm{~m}$ elevation) on estimates of EOO using data for Martellidendron, all of which are restricted to lowland habitats and threatened by fragmentation and forest loss.

Geographic data on Malagasy Pandanaceae were analysed with WORLDMAP (Williams, 2000) using 1/4degree grid cells $($ c. $27 * 27 \mathrm{~km}$ ) to calculate range size rarity (expressed as the percentage aggregated reciprocal range size for all species per grid cell), species richness (a count of species per grid cell), irreplaceability (presence in a cell of the only known populations of one or more species), and rarity (the summed inverse range size for all species present in a cell). The latter is a function of both endemism and richness, and is also referred to as endemism richness (Kier \& Barthlott, 2001). WORLDMAP was also used to calculate the correlation between richness and rarity using Spearman's non-parametric rank correlation coefficient rho. Analyses were performed on the 87 species for which adequate information is available; the 4 species assessed as DD (Appendix) were excluded. Geographic distribution was also plotted on maps of remaining vegetation (Steiniger et al., 2003) and elevation (US Geological Survey, 1996).

\section{Results}

A summary of the number of species assigned to each Red List category using the three methods of assessment is presented in Table 1. Application of the three methods to data from herbarium specimens yielded striking differences in the proportion of species assessed as threatened, from $64 \%$ using the approach of Willis et al. (2003) to $100 \%$ using a $3 * 3 \mathrm{~km}$ grid cell size. Using a 3 * $3 \mathrm{~km}$ grid but taking field observations of population decline and sensitivity to disturbance into account resulted in $95 \%$ of the species assessed as threatened (Table 1). The Appendix gives the Red List assessments of all 91 species assessed using this latter method. All nine CR species belong to Pandanus, only one of which (P. insuetus) occurs in a protected area. Four of the eight CR species not encompassed within protected areas occur in littoral forest, and one each in lowland humid forest, mid elevation forest, remnant forest parcels on the Central High Plateau, and western/northern deciduous forests. Among the 74 species categorized as EN or VU, 12 are not known to occur in protected areas and nine of these are endemic to littoral forest, two species are restricted to low and mid elevation forest, and one to

Table 1 Number of Malagasy Pandanaceae (and \% of 87 species assessed) assigned to Red List categories (IUCN, 2001) based on application of the methodologies proposed by Schatz et al. (2000), Willis et al. (2003), a $3 * 3 \mathrm{~km}$ grid cell size, and a $3 * 3 \mathrm{~km}$ grid incorporating field observations (see text for details). The four species categorized as Data Deficient are omitted.

\begin{tabular}{|c|c|c|c|c|c|}
\hline \multirow[b]{2}{*}{ Method } & \multicolumn{4}{|c|}{ IUCN category* } & \multirow{2}{*}{$\begin{array}{l}\text { Total no. threatened } \\
(\mathrm{CR}+\mathrm{EN}+\mathrm{VU})\end{array}$} \\
\hline & $\mathrm{CR}$ & EN & VU & LC & \\
\hline Willis et al. (2003) & $10(11)$ & $21(24)$ & $25(29)$ & $31(36)$ & $56(64)$ \\
\hline Schatz et al. (2000) & $6(7)$ & $41(47)$ & $38(44)$ & $2(2)$ & $85(98)$ \\
\hline $3 * 3 \mathrm{~km}$ grid & $9(10)$ & $62(71)$ & $16(18)$ & $0(0)$ & $87(100)$ \\
\hline $3 * 3 \mathrm{~km}$ grid with field observations & $9(10)$ & $31(36)$ & $43(49)$ & $4(4)$ & $83(95)$ \\
\hline
\end{tabular}

${ }^{*} \mathrm{CR}$, Critically Endangered; EN, Endangered; VU, Vulnerable; LC, Least Concern 
the central highlands. The four species (4\%) assessed as Least Concern (which indicates they are not threatened with extinction according to the Red List criteria) are widespread (EOO $>20,000 \mathrm{~km}^{2}$ ). Four species (4\%) were categorized as DD because their taxonomic status has not yet been fully clarified.

When calculations of EOO were adjusted by removing clearly unsuitable habitat for the two species of Martellidendron assessed as EN, the estimated EOO values were reduced from 1,960 to $863 \mathrm{~km}^{2}$ for $M$. androcephalanthos and from 717 to $389 \mathrm{~km}^{2}$ for M. karaka (Fig. 2C).

The highest local species richness of Malagasy Pandanaceae (10 spp.) occurs in a single 1/4-degree grid cell containing the Manongarivo Special Reserve in the north-east of the island (Fig. 1). Two other protected areas (Tsaratanana and Perinet) each contain nine species. Other areas of high species richness (7-8 spp.) include two National Parks within humid forest (Mananara-Nord and Marojejy) and several unprotected littoral forest sites along the east coast (Fig. 2A).

Centres of high endemism, as indicated by the highest endemism richness scores (7.66-14.35\%) are found in four protected areas (Tsaratanana, Manongarivo, Marojejy and Montagne d'Ambre; Fig. 2A). Relatively high rarity values $(>3 \%)$ also occur at Perinet and in several unprotected littoral forest sites. There was a strong positive correlation ( $r h o=0.782$ ) between endemism richness and species richness.

Nineteen species $(21 \%)$ do not occur in any protected area (Fig. 2B) and a minimum of 10 cells are necessary to encompass them all, four of which are irreplaceable. These same 10 cells collectively encompass $48 \%$ (44) of all species. The minimum number of cells required to ensure that all Malagasy Pandanaceae are represented at least once includes 16 additional cells (i.e. 26 in total). All 87 Malagasy Pandanaceae (excluding DD species) occur within the cells collectively occupied by the 28 rarest species (i.e. those occurring in only one or two cells).

\section{Discussion}

Pandanaceae are important components of many vegetation types in Madagascar, although they are best represented in humid and subhumid forests and riparian communities. They also present a wide variety of distribution patterns, including widespread to locally restricted taxa, species with nearly circular or linear ranges, and with almost continuous to highly disjunct and fragmented distributions. Although the method of Willis et al. (2003) is useful for calculating AOO for species with restricted ranges and approximately circular distributions, setting grid cell size using 1/10 of the maximum distance between subpopulations is inappropriate for taxa with widespread distributions that span both suitable and intervening unsuitable habitat. This method is also inappropriate for linear or highly disjunct distributions because it leads to the selection of large grid cells, resulting in an underassessment of threatened species (Table 1). Furthermore, this method incorporates a dependency of $\mathrm{AOO}$ on EOO, exacerbating an already inherent scale dependency. In these instances the method proposed by Schatz et al. (2000), using $10 * 10 \mathrm{~km}$ grid cells to calculate AOO, is preferable in Madagascar (Good et al., 2006); e.g. for littoral forest endemics restricted to a narrow band $(<10 \mathrm{~km}$ wide) along the east coast (Consiglio et al., 2006). This method is, however, less well suited for species with very restricted ranges because AOO is overestimated, leading again to an under-assessment of CR species (Table 1). A combined approach using one or other of these methods, depending on distribution shape and fragmentation, would exploit their respective strengths, although choosing between them is necessarily subjective, introducing a bias that could, however, be avoided by consistently employing a single grid size, reducing uncertainty (Keith et al., 2000). For Malagasy Pandanaceae use of a $3 * 3 \mathrm{~km}$ grid results in the highest number of species assessed as threatened (Table 1) of the three methods used, and may not best reflect biological reality. A more realistic approach is to incorporate field observations (Appendix, Table 1) that evaluate population decline, although it remains impossible to eliminate assessor bias altogether (Regan et al., 2005). In reality, complete objectivity is unachievable; selecting a grid size for uniform application, as recommended by IUCN, is itself subjective.

Estimates of EOO can be improved by removing unsuitable habitat (IUCN, 2001) or by using an alphahull, in which a highly disjunct distribution is separated into several distinct hulls (Burgman \& Fox, 2003). Such methods can, however, be difficult to apply using collection data and may lead to substantial biases if there are few records or if recorded locations are imprecise or contain errors. While no change in threat classification resulted when we removed unsuitable habitat for species of Martellidendron, the different EOO values obtained illustrate how such corrections could significantly affect Red List assessments.

The highest levels of both species richness and endemism richness occur in northern Madagascar, especially in the higher mountains (Manongarivo, Marojejy and Tsaratanana), where $95 \%$ of the species growing at $>800 \mathrm{~m}$ altitude are local endemics (i.e. restricted to one or few cells). These results are not surprising given that nearly one third of Malagasy Pandanaceae (27 of 91 spp.) are endemic to the northern 

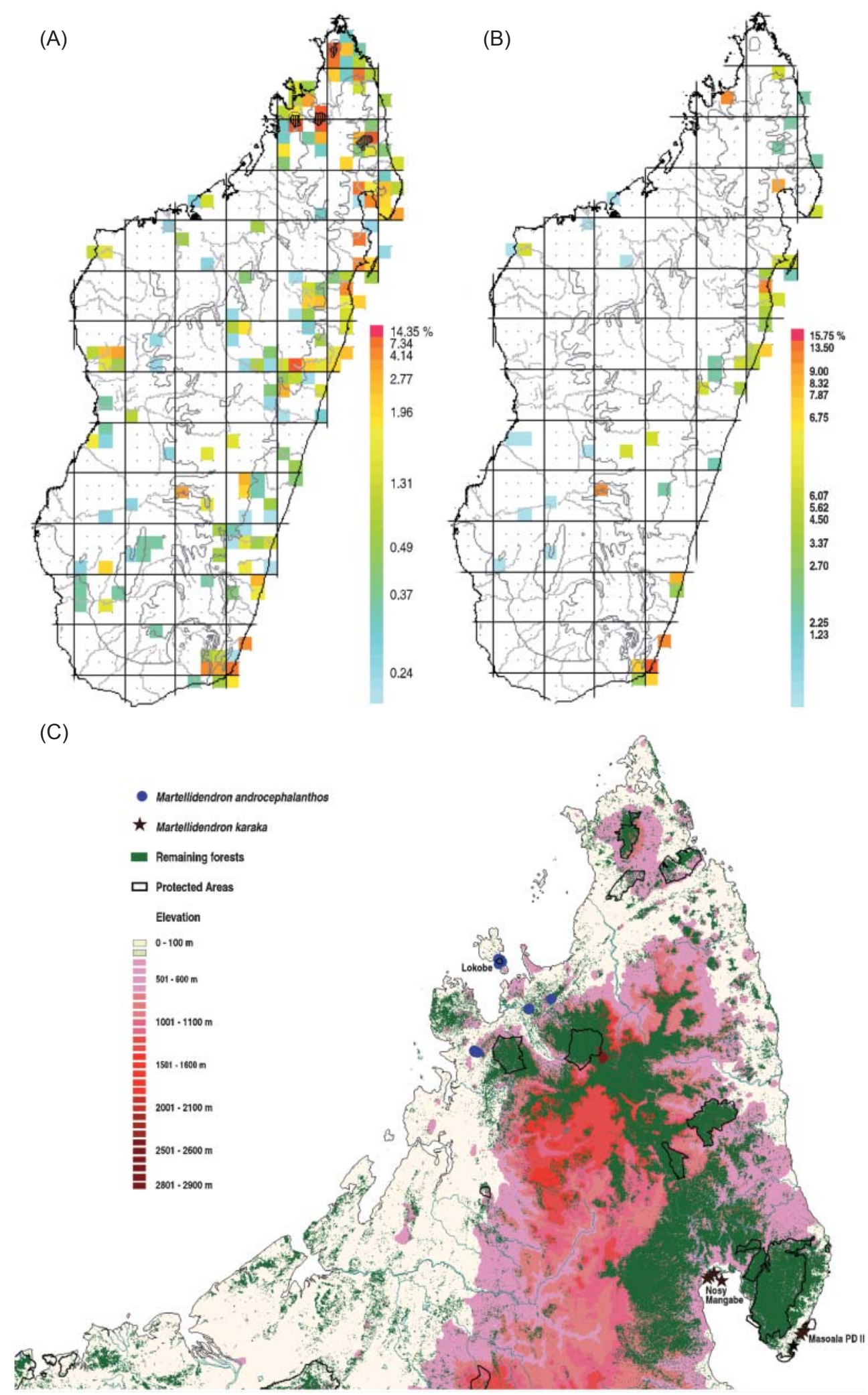

Fig. 2 (A) Endemism richness (see text for details) for all 87 species of Pandanaceae assessed (i.e. excluding the 4 species assessed as Data Deficient) and the four Protected Areas (vertical hatching) with the highest scores. (B) Endemism richness of 19 species not currently included in Madagascar's protected area network. (C) Distribution of two Endangered species of Martellidendron in northern Madagascar, with remaining forests as of 2003 (map from Steiniger et al., 2003). 
Table 2 Priority areas for Pandanaceae conservation, with size of area and threatened species of Pandanaceae occurring in each location.

\begin{tabular}{|c|c|c|}
\hline Location & Area (ha) & Species (Red List category)* \\
\hline \multicolumn{3}{|l|}{ Littoral forests } \\
\hline Baie d'Antongil (forests around the bay) & 185 & $\begin{array}{l}\text { Martellidendron karaka (EN), Pandanus } \\
\text { bipyramidatus (VU), P. columnaris (VU), } \\
\text { P. concretus (VU), P. guillaumetii (VU), } \\
\text { P. insuetus (CR), P. imerinensis (VU), } \\
\text { P. longecuspidatus (VU), P. princeps (CR) }\end{array}$ \\
\hline Analalava-Foulepointe-Soanierana-Ivongo-Tampolo & 2,613 & $\begin{array}{l}\text { P. callmanderiana (CR), P. cephalothus (VU), } \\
\text { P. comatus (EN), P. concretus (VU), } \\
P . \text { guillaumetii (VU), P. malgassicus (VU), } \\
\text { P. neoleptopodus (EN), P. pseudocollinus (EN), } \\
\text { P. platyphyllus (EN), P. rollotii (VU), } \\
\text { P. sylvicola (CR) }\end{array}$ \\
\hline Fort-Dauphin region (Saint-Luce) & 457 & $\begin{array}{l}\text { P. bipyramidatus }(\mathrm{VU}), \boldsymbol{P} \text {. dauphinensis }(\mathrm{CR}), \\
\boldsymbol{P} \text {. longistylus }(\mathrm{EN}), \boldsymbol{P} \text {. peyriarasii }(\mathrm{CR}), \\
\text { P. platyphyllus }(\mathrm{VU}), \boldsymbol{P} \text {. rollotii }(\mathrm{VU})\end{array}$ \\
\hline \multicolumn{3}{|l|}{ Natural vegetation of the highlands } \\
\hline Andringitra region ( $\mathrm{E}$ side outside the protected area) & 46,649 & P. ambalavaoensis (CR) \\
\hline Itremo region (forest patches) & 405 & P. bakeri (CR) \\
\hline \multicolumn{3}{|l|}{ Northern and Western deciduous forests } \\
\hline Cap Saint André (40 km south) & 5,858 & $\begin{array}{l}\text { P. ambongensis }(\mathrm{VU}), P \text {. perrieri }(\mathrm{CR}) \text {, } \\
\text { P. stellatus (VU) }\end{array}$ \\
\hline $\begin{array}{l}\text { Forest block in the Daraina region (Ambilondamba, } \\
\text { Ampondrabe, Antsahabe, Binara \& Bobankora) }\end{array}$ & 17,796 & $\begin{array}{l}\text { P. analamerensis }(\mathrm{VU}), \text { P. coriaceus }(\mathrm{VU}), \\
P . \text { grallatus }(\mathrm{EN}), \text { P. latistigmaticus }(\mathrm{EN}), \\
P . \text { perrieri }(\mathrm{CR})\end{array}$ \\
\hline $\begin{array}{l}\text { Mangoky basin (forest blocks along rivers in the Mangoky Basin) } \\
\text { Eastern and Western rainforests }\end{array}$ & 84,477 & P. ambongensis (VU) \\
\hline Lakato forest & 555 & M. cruciatum (VU), P. freycinetioides (VU) \\
\hline Galoko massif (NE of Ambanja) & 8,720 & $\begin{array}{l}\text { M. androcephalanthos (EN), M. cruciatum (VU), } \\
\text { P. sp. nov 'neosermollii' ined. (CR), } \\
\text { P. mammillaris (EN) }\end{array}$ \\
\hline South of Moramanga (forest patches around Anosibe an'ala) & 1,730 & $\begin{array}{l}\text { P. ceratophorus (VU), P. kimlangii (VU), } \\
\text { P. leptopodus (VU), P. macrophyllus (CR) }\end{array}$ \\
\hline
\end{tabular}

*Species not occurring in the protected area network are in bold. CR, Critically Endangered; EN, Endangered; VU, Vulnerable

part of the island (Callmander et al., 2003c). However, most threatened Pandanaceae occur in low to mid elevation eastern humid forests, including littoral forests (Schatz et al., 2000; Randrianasolo et al., 2002; Good et al., 2006).

Our analyses show that 19 Malagasy Pandanaceae are not included in the country's protected area network but can be encompassed in a near minimum set of $10^{1 / 4-}$ degree cells, and these therefore represent the highest priorities for Pandanaceae conservation. If these cells are added to the existing protected area network, which already includes the 16 additional cells required to encompass all Malagasy Pandanaceae, each member of the family would be protected in at least one site. These 10 new priority areas include four major vegetation types (Table 2): littoral forests, natural vegetation on the central highlands, deciduous forests in the north and west, and rainforests in the east and north-west. The first two are suffering exceptionally high rates of deforestation; in 1990 they had $<10 \%$ of their original cover remaining (Green \& Sussman, 1990) and have considerably less today. Neither of these vegetation types has adequate coverage in protected areas, even though they contain large numbers of locally endemic species. Littoral forests are severely under-represented in the protected area network, with just four small parcels totalling $695 \mathrm{~km}^{2}$ (ANGAP, 2005; Consiglio et al., 2006). Of the 10 new sites, 3 have been granted preliminary protected area status (Daraina, AnalalavaTampolo, and Saint Luce).

One goal of conservation planners is maximum inclusion of biodiversity in protected areas. Our study shows that by conserving sites in Madagascar with the rarest Pandanaceae (those occurring in only one or a few areas) along with species not known to occur in protected areas, we can achieve protection for the entire family. This is also true for Madagascar's endemic plant families (Schatz et al., 2003; Raharimampionona et al., 2006), some members of which are restricted to these same areas. Application of this method to other groups (now being conducted) is confirming the importance of 
these sites and revealing additional conservation priorities. Ultimately, the identification of such key sites is a fundamental component of developing a comprehensive strategy for biodiversity protection, which can be facilitated by carefully evaluating the conservation status of well-delimited species using geo-referenced data from natural history collections.

Our study confirms that conservation planning in Madagascar must include as much of the remaining lowland forest of the east coast as possible, especially littoral forests (Consiglio et al., 2006); stands between the Baie d'Antongil (central north-east) and Tampolo (central east) are of particular importance for Pandanaceae, as they are for the endemic plant families (Schatz et al., 2003).

For Red List assessments the appropriate selection of grid cell size is dependent upon the shape, size and homogeneity of a species' distribution, as manifested in part by its extent of occurrence. By selectively applying complementary methods for choosing grid size (Schatz et al., 2000; Willis et al., 2003; IUCN \& SSC, 2004), depending on distribution attributes, we have shown that there is no single best approach to selecting an appropriate scale for calculating area of occurrence, and have demonstrated that the method chosen can influence threat assessments. With $75 \%$ of Malagasy Pandanaceae threatened, conservation action must be taken immediately to ensure their continued survival. The careful analysis of specimen data using appropriate methods can make an important contribution to this process by identifying threatened species and revealing the highest priority sites for their conservation.

\section{Acknowledgements}

We thank the Parc Botanique et Zoologique de Tsimbazaza, ANGAP (Association Nationale pour la Gestion des Aires Protégées), and the Missouri Botanical Garden's office in Antananarivo (especially Lalao Andriamahefarivo) for local assistance, and Bette Loiselle (University of Missouri-St. Louis, USA), Prof. Philippe Küpfer (Université de Neuchâtel) and Wendy Strahm (IUCN, Gland, Switzerland) for support before and during this study. We are grateful to Craig HiltonTaylor (IUCN, Cambridge, UK), Mark Burgman (University of Melbourne, Australia) and Justin Moat (Royal Botanic Gardens, Kew, UK) for kind responses to queries regarding methods, and to two anonymous reviewers for helpful comments. This work was supported by grants to MWC from the Swiss National Science Foundation (No. PBNE2-102378), National Geographic Society (No. 04065) and Conservation International-Madagascar (Convention 234).

\section{References}

Achard, F., Eva, H.D., Stibig, H.-J., Mayaux, P., Gallego, J., Richards, T. \& Malingreau, J.-P. (2002) Determination of deforestation rates in the world's humid tropical forests. Science, 297, 999-1002.

ANGAP (2005) Liste des Parcs et Réserves de Madagascar. Http:/ / www.parcs-madagascar.com/liste.htm [accessed 10 January 2007].

Burgman, M.A. \& Fox, J.C. (2003) Bias in species range estimates from minimum convex polygons: implications for conservation and options for improved planning. Animal Conservation, 6, 19-28.

Callmander, M.W., Chassot, P., Küpfer, P. \& Lowry II, P.P. (2003a) Recognition of Martellidendron, a new genus of Pandanaceae, and its biogeographic implications. Taxon, 52, 747-762.

Callmander, M.W. \& Laivao, M.O. (2002) Révision de Pandanus sect. Dauphinensia St. John (Pandanaceae) à Madagascar. Botanica Helvetica, 112, 47-67.

Callmander, M.W., Laivao, M.O. \& Wohlhauser, S. (2003b) Les Pandanus sect. Acanthostyla Martelli (Pandanaceae) d'altitude du Nord de Madagascar, avec description de deux nouvelles espèces. Candollea, 58, 63-74.

Callmander, M.W., Schatz, G.E. \& Lowry II, P.P. (2005) IUCN Red List assessment and the Global Strategy for Plant Conservation: taxonomists must act now. Taxon, 54, 1047-1050.

Callmander, M.W., Wohlhauser, S. \& Gautier, L. (2003c) Notes biogéographiques sur les Pandanaceae du nord de Madagascar. Candollea, 58, 351-367.

Callmander, M.W., Wohlhauser, S. \& Laivao, M.O. (2001) Une nouvelle section du genre Pandanus (Pandanaceae) à Madagascar: Pandanus sect. Tridentistigma. Adansonia, sér. 3, 23, 49-57.

Consiglio, T., Schatz, G.E., McPherson, G., Lowry II, P.P., Rabenantoandro, J., Rogers, Z.S., Rabevohitra, R. \& Rabehevitra, D. (2006) Deforestation and plant diversity of Madagascar's littoral forests. Conservation Biology, 20, 1799-1803.

Cornet, A. (1974) Essai de cartographie bioclimatique à Madagascar. Notice explicative $N^{\circ} 55$, ORSTOM, Paris, France.

Gärdenfors, U., Hilton-Taylor, C., Mace, G. \& Rodríguez, J.P. (2001) The application of IUCN Red List Criteria at regional levels. Conservation Biology, 15, 1206-1212.

Good, T.C., Zjhra, M.L. \& Kremen, C. (2006) Addressing data deficiency in classifying extinction risk: a case study of a radiation of Bignoniaceae from Madagascar. Conservation Biology, 20, 1099-1110.

Goodman, S.M. \& Benstead, J.P. (2005) Updated estimates of biotic diversity and endemism for Madagascar. Oryx, 39, 73-77.

Green, G.M. \& Sussman, R.W. (1990) Deforestation history of the eastern rainforest of Madagascar from satellite image. Science, 248, 212-215.

IUCN (2001) 2001 Categories and Criteria (version 3.1). IUCN, Gland, Switzerland [http://www.redlist.org/info/ categories_criteria2001.html, accessed 20 February 2007].

IUCN (2006) 2006 IUCN Red List of Threatened Species. IUCN, Gland, Switzerland [http://www.redlist.org, accessed 10 January 2007].

IUCN \& SSC (2004) Guidelines for using the IUCN Red List Categories and Criteria. IUCN, Gland, Switzerland.

Keith, D.A., Auld, T.D., Ooi, M.K.J. \& Mackenzie, D.E. (2000) Sensitivity analyses of decision rules in World Conservation Union (IUCN) Red List Criteria using Australian plants. Biological Conservation, 94, 311-319. 
Kier, G. \& Barthlott, W. (2001) Measuring and mapping endemism and species richness: a new methodological approach and its application on the flora of Africa. Biodiversity and Conservation, 10, 1513-1529.

Laivao, M.O., Callmander, M.W. \& Buerki, S. (2006) Sur les Pandanus (Pandanaceae) à stigmates saillants de la côte est de Madagascar. Adansonia, sér. 3, 28, 267-285.

Laivao, M.O., Callmander, M.W. \& Wohlhauser, S. (2000) Une espèce nouvelle de Pandanus sect. Martellidendron (Pandanaceae) de la péninsule de Masoala, Madagascar. Botanica Helvetica, 110, 41-49.

Myers, N. \& Knoll, H.A. (2001) The biotic crisis and the future of evolution. Proceedings of the National Academy of Sciences, 98, 5389-5392.

Myers, N., Mittermeier, R.A., Mittermeier, C.G., Da Fonseca, G.A.B. \& Kent, J. (2000) Biodiversity hotspots for conservation priorities. Nature, 403, 853-858.

Phillipson, P.B., Schatz, G.E., Lowry II, P.P. \& Labat, J.-N. (2006) A catalogue of the vascular plants of Madagascar. In Taxonomy and Ecology of African Plants: Their Conservation and Sustainable Use (eds S.A. Ghazanfar \& H.J. Beentje), pp. 613-627. Proceedings 17th AETFAT Congress, Addis Ababa, Ethiopia \& Royal Botanic Gardens, Kew, London, UK.

Raharimampionona, J., Andriambololonera, S., Schatz, G.E., Lowry II, P.P., Rabarimanarivo, M., Ratodisoa, A. \& Ravololomanana, N. (2006) Identification des aires prioritaires pour la conservation des plantes à Madagascar: utilisation des données botaniques pour définir les priorités en matière de conservation. In Taxonomy and Ecology of African Plants: Their Conservation and Sustainable Use (eds S.A. Ghazanfar \& H.J. Beentje), pp. 447-456. Proceedings 17th AETFAT Congress, Addis Ababa, Ethiopia \& Royal Botanic Gardens, Kew, London, UK.

Randrianasolo, A., Miller, J.S. \& Consiglio, T.K. (2002) Application of IUCN Criteria and Red List Categories on species of five Anacardiaceae genera in Madagascar. Biodiversity and Conservation, 7, 1289-1300.

Regan, T.J., Burgman, M.A., McCarthy, M.A., Master, L.L., Keith, D.A., Mace, G.M. \& Andelman, S.J. (2005) The consistency of extinction risk classification protocols. Conservation Biology, 19, 1969-1977.

Rodrigues, A.S.L., Pilgrim, J.D., Lamoreux, J.F., Hoffman, M. \& Brooks, T.M. (2006) The value of the IUCN Red List for conservation. Trends in Ecology \& Evolution, 21, 71-76.

Schatz, G.E. (2000) Endemism in the Malagasy tree flora. In Diversité et Endémisme à Madagascar (eds W.R. Lourenço \& S.M. Goodman), pp. 1-9. Mémoires de la Société Biogéographie, Paris, France.

Schatz, G.E. (2001) Generic Tree Flora of Madagascar. [Flore Générique des Arbres de Madagascar]. Missouri Botanical Garden, SaintLouis, USA \& Royal Botanic Gardens, Kew, UK.

Schatz, G.E. (2002) Taxonomy and herbaria in service of plant conservation: lessons from Madagascar's endemic families. Annals Missouri Botanical Garden, 89, 145-152.

Schatz, G.E., Andriambololonera, S., Randriampionona, J. \& Lowry II, P.P. (2003) Rediscovering Lost Species. Http:/ /
www.mobot.org/MOBOT/Madagasc/Rediscovering $\%$ 20Lost\%20Species_files/frame.htm [accessed 10 January 2007].

Schatz, G.E., Birkinshaw, C., Lowry II, P.P., Randriantafika, F. \& Ratovoson, F. (2000) The endemic plant families of Madagascar project: integrating taxonomy and conservation. In Diversité et Endémisme à Madagascar (eds W.R. Lourenço \& S.M. Goodman), pp. 11-24. Mémoires de la Société Biogéographie, Paris, France.

Schatz, G.E. \& Lescot, M. (1996) Gazetteer to Malagasy Botanical Collecting Localities. Http:/ /www.mobot.org/MOBOT/ research/madagascar/gazetteer/ [accessed 10 January 2007]. Steiniger, M.K., Harper, G.J. \& Tucker, C.J. (2003) Forest Cover Fragmentation and Clearance in Madagascar. Centre for Applied Biodiversity Science, Conservation International, Arlington, USA \& Nasa Goddard Space Flight Center, Washington, DC, USA.

US Geological Survey (1996) Global 30-Arc-Second Elevation Data Set. US Geological Survey, Sioux Falls, USA.

Williams, P.H. (2000) WORLDMAP. Software and help document 4.2. Privately distributed, London, UK.

Willis, F., Moat, J. \& Paton, A. (2003) Defining a role for herbarium data in Red List assessments: a case study of Plectranthus from eastern and southern tropical Africa. Biodiversity and Conservation, 12, 1537-1552.

\section{Appendix}

The Appendix for this article is available online at http://journals.cambridge.org

\section{Biogeographical sketches}

Martin W. Callmander's research interests include the inventory and systematics of the Malagasy flora, Malagasy plant biogeography, and using botanical data to evaluate endemism and conserve the remaining forests of this biodiversity hotspot.

George E. Schatz's research interests include the woody flora of Madagascar, the use of primary occurrence data for extinction risk assessment, and species distribution modelling.

Porter P. Lowry II's research interests include the inventory and systematics of the Malagasy flora, and assessing patterns of biological diversity to identify threatened species and priority areas for conservation.

Michel O. Laivao, J. Raharimampionona, S. Andriambololonera and T. Raminosoa work for Missouri Botanical Garden's research and conservation programme in Madagascar. They are currently working on a threat assessment of endemic Malagasy plant species.

Trisha Consiglio specializes in geographical information systems, using tools that include remote sensing and species distribution modelling to identify key areas of plant diversity and endemism. 